\title{
Development of Low Energy Gap and Fully Regioregular Polythienylenevinylene Derivative
}

\author{
Tanya M. S. David, ${ }^{1}$ Cheng Zhang, ${ }^{1,2}$ and Sam-Shajing Sun ${ }^{1}$ \\ ${ }^{1}$ Center for Materials Research, Norfolk State University, 700 Park Avenue, Norfolk, VA 23504, USA \\ ${ }^{2}$ Department of Chemistry and Biochemistry, South Dakota State University, P.O. Box 2202, Brookings, SD 57007, USA \\ Correspondence should be addressed to Sam-Shajing Sun; ssun@nsu.edu
}

Received 20 June 2014; Accepted 15 August 2014; Published 3 September 2014

Academic Editor: Sirilak Sattayasamitsathit

Copyright (C) 2014 Tanya M. S. David et al. This is an open access article distributed under the Creative Commons Attribution License, which permits unrestricted use, distribution, and reproduction in any medium, provided the original work is properly cited.

Low energy gap and fully regioregular conjugated polymers find its wide use in solar energy conversion applications. This paper will first briefly review this type of polymers and also report synthesis and characterization of a specific example new polymer, a low energy gap, fully regioregular, terminal functionalized, and processable conjugated polymer poly-(3-dodecyloxy-2,5-thienylene vinylene) or PDDTV. The polymer exhibited an optical energy gap of $1.46 \mathrm{eV}$ based on the UV-vis-NIR absorption spectrum. The electrochemically measured highest occupied molecular orbital (HOMO) level is $-4.79 \mathrm{eV}$, resulting in the lowest unoccupied molecular orbital (LUMO) level of $-3.33 \mathrm{eV}$ based on optical energy gap. The polymer was synthesized via Horner-Emmons condensation and is fairly soluble in common organic solvents such as tetrahydrofuran and chloroform with gentle heating. DSC showed two endothermic peaks at $67^{\circ} \mathrm{C}$ and $227^{\circ} \mathrm{C}$ that can be attributed to transitions between crystalline and liquid states. The polymer is thermally stable up to about $300^{\circ} \mathrm{C}$. This polymer appears very promising for cost-effective solar cell applications.

\section{Introduction}

Availability of organic conjugated polymers with different frontier orbitals and energy gaps is crucial and vital for the development and optimizations of polymer based optoelectronic devices such as solar cells or photodetectors. Polythienylene vinylene (PTVs) are one class of conjugated polymers that are very attractive for optoelectronic applications due to its relatively lower energy gaps compared to polyphenylenevinylenes (PPVs) and polythiophenes (PThs), and particularly its capability of forming regioregular polymers with high crystallinity in solid states [1]. PTVs are derivatives of polythiophenes that have vinylene linkages between the aromatic thiophene rings. With the combination of the low resonance energy and good thermal stability of the thiophene ring, incorporation of the vinylene linkage as well as other tailoring methods into the macroscopic structure all contribute to the very promising electronic and photonic properties that have been observed from PTVs [2$4]$. The introduction of the vinylene linkage into the polymer main chain lowers band gaps by about $0.3 \mathrm{eV}$ in comparison to polythiophenes [4]. One of the appealing features about PTVs is that chemical modification for tuning optoelectronic properties can be done with relative ease and gives rise to promising properties.

PTVs have been synthesized using a number of synthetic methods such as Ni-catalyzed Grignard $[2,5,6]$, Stille coupling [7-9], Heck coupling [2], Horner-Emmons [1, 10], acyclic diene metathesis (ADMET) [11], dithiocarbamate route [12,13], sulphinyl route [14], and bis(xanthate) route [14] (Figure 1).

Many of these synthetic methods give regiorandom coupling (head-head and tail-tail) (Figure 2). However, it has been shown that the Ni-catalyzed Grignard method and the Horner-Emmons method can promote 100\% regioregular coupling (head-tail).

Alkoxy-substituted PTV (RO-PTV) has been synthesized by many of these methods; however, the resulting polymers have a regiorandom coupling $[7,12]$. From our earlier work on the synthesis of a 3-dodecyl-substituted PTV (RR- $\mathrm{C}_{12}$ PTV) via Horner-Emmons reaction as well as Stille coupling reaction [1], we learned that PTV from the Stille reaction was 
<smiles>[X]c1cc([R])c([Y])s1</smiles><smiles>[X]c1cc([R])c([X])s1</smiles>

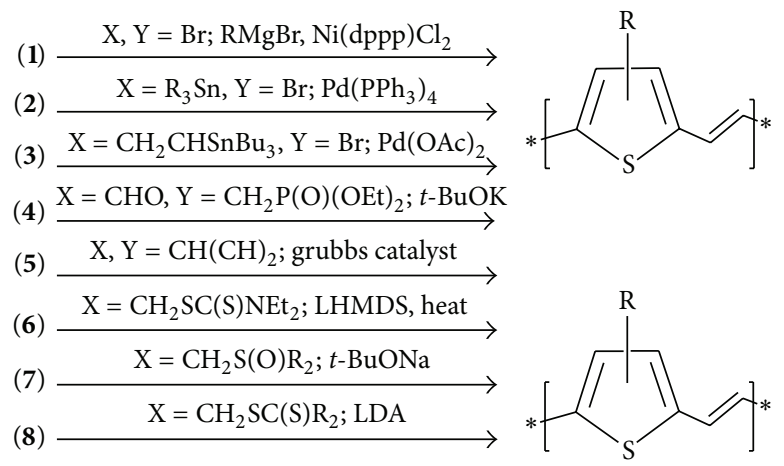

FIGURE 1: Various synthetic routes to synthesize PTV: 1 [2, 5, 6], 2 [7-9], 3 [2], 4 [1, 10], 5 [11], 6 [12, 13], 7 [14], and 8 [14].<smiles>[R]c1cc([Tl])sc1/C=C/c1sc([Tl])cc1[R]</smiles>

Head-head<smiles>[R]c1cc(/C=C/c2cc([R])c(I)s2)sc1C</smiles>

Tail-tail<smiles>[R]c1cc(/C=C/c2sc(C)cc2[R])sc1C</smiles>

Head-tail

FIGURE 2: Regiorandom and regioregular coupling of PTV polymer.

neither regioregular nor structurally free of defect. On the other hand, Horner-Emmons reaction produced $\mathrm{C}_{12}$-PTV with $100 \%$ head-to-tail regioregularity, which showed much higher crystallinity than the regiorandom $\mathrm{C}_{12}$-PTV obtained via the Stille coupling reaction [1].

In this work, a 3-dodecyloxy-substituted PTV $\left(\mathrm{C}_{12} \mathrm{O}\right.$ PTV) or PDDTV, the alkoxy analog of our previously synthesized PTV, was synthesized by Horner-Emmons reaction utilizing asymmetrically functionalized monomers. A different synthetic approach was taken for the synthesis of PDDTV than our preciously synthesized RR-C 12 -PTV, which proved more favorable for the more electron rich alkoxy-substituted thiophene. Compared to PTV, the new PDDTV exhibits the advantage of having a lower band gap due to the electron donating properties of the alkoxy substituent and better for matching photons of similar energy on surface of the earth. The optoelectronic properties of the polymer will also be discussed.

\section{Experimental Section}

All commercially available products were used as received. Proton and carbon NMR spectra were recorded at a $300 \mathrm{MHz}$ NMR spectrometer. Flash column chromatography was performed using Sigma-Aldrich silica gel 60 (200-400 mesh). Electrochemical studies (cyclic voltammetry) were performed on a Bioanalytical (BAS) Epsilon-100w tri-electrode cell system. Three electrodes are a glassy carbon working electrode, an ancillary $\mathrm{Pt}$ electrode, and a silver reference electrode (in a $\mathrm{CH}_{3} \mathrm{CN}$ solution of $0.01 \mathrm{M} \mathrm{AgNO}_{3}$ and $0.1 \mathrm{M}$ TBA-HFP). The polymer samples were dried directly on the electrode and placed a solution of anhydrous $\mathrm{CH}_{3} \mathrm{CN}$ with
$0.10 \mathrm{M}$ tetrabutylammonium hexafluorophosphate (TBAHFP). Ferrocene (2 mM in 0.10 M TBA-HFP/THF solution) was used as an internal reference standard (its HOMO level of $-4.8 \mathrm{eV}$ was used in calculations). Before starting a measurement, dry nitrogen gas was bubbled through the solution for at least $10 \mathrm{~min}$ to remove any dissolved oxygen. Between the experiments, the surface of the electrodes was cleaned or polished. Scan rate was $100 \mathrm{mV} / \mathrm{s}$.

2.1. 3-Methoxythiophene (1). Literature method was followed with minor modifications $[15,16]$.

Copper bromide $(9.629 \mathrm{~g}, 67 \mathrm{mmol})$ was weighed in a $500 \mathrm{~mL}$ round bottom flask and placed in a nitrogen atmosphere glove box. Within the glove box sodium methoxide (54.067 g, $1000 \mathrm{mmol})$ and dry NMP (171.476 g, $1729 \mathrm{mmol})$ were added, and the flask was stoppered and removed from the glove box. With a syringe, 3-bromothiophene $(108.130 \mathrm{~g}$, $663.2 \mathrm{mmol}$ ) was added, and the solid reagents were allowed to dissolve at $110^{\circ} \mathrm{C}$ for $15 \mathrm{~min}$. After the addition of anhydrous methanol $(100 \mathrm{~mL})$, the reaction was allowed to reflux at $110^{\circ} \mathrm{C}$ for 3 hours and 15 minutes. Throughout the reaction time a receiving flask collected vaporized methanol. At reaction end, the product was separated by vacuum distillation, followed by washing the organic layer with water $(100 \mathrm{~mL} \times 3)$ and aqueous layer with pentane $(100 \mathrm{~mL} \times 3)$. The organic layer was then dried with magnesium sulfate $\left(\mathrm{MgSO}_{4}\right)$ and filtered, and all the solvent was removed by a rotary evaporator. The product was pale yellow oil with a $78.59 \%$ yield. NMR data match with the literature data.

2.2. 3-Dodecyloxythiophene (2). The literature method for 3octylthiophene was followed [17]. 
3-Methoxythiophene $(26.86 \mathrm{~g}, 235 \mathrm{mmol})$, p-toluenesulfonic acid monohydrate $(0.91 \mathrm{~g}, 4.78 \mathrm{mmol})$, and 1dodecanol $(39.21 \mathrm{~g}, 210.4 \mathrm{mmol})$ were mixed together in a $1000 \mathrm{~mL}$ round bottom flask and refluxed at $92^{\circ} \mathrm{C}$ at low pressure ( 220 mTorr-132 mTorr) for 3.5 hours. The reaction was allowed to cool down to room temperature, followed by the addition of a 1:1 molar equivalent of sodium carbonate to $\mathrm{p}$-toluenesulfonic acid in order to quench the acid. The solution was then washed with water $(100 \mathrm{~mL})$ and hexane $(100 \mathrm{~mL})$. Subsequent washings of the aqueous and organic layer were done with hexane $(50 \mathrm{~mL} \times 3)$ and water $(50 \mathrm{~mL}$ $\times 3$ ), respectively. Separation of organic layer was done by low pressure to vacuum distillation, and purification was performed by column chromatography (hexane as eluent). The product was a light green solid with a $91.64 \%(57.88 \mathrm{~g})$ yield. ${ }^{1} \mathrm{H}$ NMR $\left(\mathrm{CDCl}_{3}\right): \delta 0.88(\mathrm{t}, 3 \mathrm{H}), 1.26(\mathrm{~m}, 18 \mathrm{H}), 1.76$ $(\mathrm{t}, 2 \mathrm{H}), 3.91(\mathrm{t}, 2 \mathrm{H}), 6.22(\mathrm{t}, 2 \mathrm{H}), 6.71(\mathrm{t}, 2 \mathrm{H}), 7.12(\mathrm{t}, 2 \mathrm{H})$. ${ }^{13}$ C NMR: $\delta 14.1,22.71,26.0,29.6,31.9,70.2,76.6\left(\mathrm{CDCl}_{3}\right)$, 96.9, 119.5, 124.4, 158.0. Anal. Calcd: C, 71.58; H, 10.51; S, 11.94. Found: C, 71.41; H, 10.57; S, 11.69.

2.3. 2,5-Dibromo-3-dodecyloxythiophene (3). NBS (45 g, $247 \mathrm{mmol} / \sim 2.7 \mathrm{~mol}$ equiv.) was dissolved in anhydrous DMF $(100 \mathrm{~mL})$ and added dropwise to a mixture of 3dodecyloxythiophene $(27.88 \mathrm{~g}, 103.8 \mathrm{mmol})$ and anhydrous DMF $(120 \mathrm{~mL})$ in a low temperature bath. The addition and the reaction were done with the exclusion of light by covering the flask in a black plastic bag. The reaction was carried out at room temperature for 3-6 hours. The product was extracted with hexane and water $(2 \mathrm{~mL} \times 5)$ and purified by column chromatography (hexane as eluent). The product retrieved was light green oil with a yield $47.97 \%(18.09 \mathrm{~g})$. ${ }^{1} \mathrm{H} \mathrm{NMR}\left(\mathrm{CDCl}_{3}\right): \delta 0.88(\mathrm{t}, 3 \mathrm{H}), 1.26(\mathrm{~m}, 18 \mathrm{H}), 1.73(\mathrm{t}, 2 \mathrm{H})$, $3.98(\mathrm{t}, 2 \mathrm{H}), 6.75(\mathrm{~s}, 2 \mathrm{H}) .{ }^{13} \mathrm{C}$ NMR: $\delta$ 14.0, 22.6, 25.7, 29.3, 72.5, $76.5\left(\mathrm{CDCl}_{3}\right), 90.5,109.3,120.8,153.8$ Anal. Calcd for $\mathrm{C}_{16} \mathrm{H}_{26} \mathrm{Br}_{2} \mathrm{OS}$ : C, 45.08; H, 6.15; Br, 37.49; $\mathrm{S}$, 7.52 Found: C, 45.18; $\mathrm{H}, 6.22 ; \mathrm{Br}, 37.27$.

2.4. 3-Dodecyloxy-2,5-diformylthiophene (4). Anhydrous THF $(40 \mathrm{~mL})$ was added to 2,5-dibromo-3-dodecyloxythiophene $(12.2 \mathrm{~g}, 28.6 \mathrm{mmol})$. This mixture was then added dropwise, by syringe, to a mixture of THF $(50 \mathrm{~mL})$ and $1.6 \mathrm{M}$ butyl lithium $(53.66 \mathrm{~mL} / 3 \mathrm{~mol}$ equiv.) that was in a dry ice/hexane bath. The reagents reacted at $\sim-78^{\circ} \mathrm{C}$ for 5 to 10 minutes and then were removed from the dry ice bath. This solution was slowly added with a syringe to anhydrous DMF ( $7.09 \mathrm{~mL}, 3.2 \mathrm{~mol}$ eq.) and allowed to react for 5 minutes after addition. The product was extracted by first washing the solution with water $(100 \mathrm{~mL})$, hexane $(100 \mathrm{~mL})$, and acetic acid $(15 \mathrm{~mL}$ to $20 \mathrm{~mL}$ ) (which was monitored using litmus paper as the acid was added) in a separatory funnel. Once the organic and aqueous solution visibly separated, the aqueous layer was discarded, and sodium carbonate was added until the organic solution was basic. The organic layer was further washed with water $(50 \mathrm{~mL} \times 4)$ and aqueous layer with hexane $(50 \mathrm{~mL} \times 4)$. The product was dried with $\mathrm{MgSO}_{4}$, solvent removed by rotary evaporator, and the product recrystallized. The filtrate from the recrystallized crystals was purified using column chromatography (1EtAc:17 hexane used as eluent). The solid yellow product had a 59.5\% $(5.527 \mathrm{~g})$ yield. ${ }^{1} \mathrm{H} \mathrm{NMR}\left(\mathrm{CDCl}_{3}\right): \delta 0.87(\mathrm{t}, 3 \mathrm{H}), 1.26(\mathrm{~m}$, $18 \mathrm{H}), 1.85(\mathrm{t}, 2 \mathrm{H}), 4.21(\mathrm{t}, 2 \mathrm{H}), 7.25(\mathrm{~s}, 1 \mathrm{H}), 9.89(\mathrm{~s}, 1 \mathrm{H})$, $10.1(\mathrm{~s}, 1 \mathrm{H}) .{ }^{13} \mathrm{C}$ NMR: $\delta$ 14.1, 22.6, 25.7, 29.6, 31.9, 72.4, 77.1 $\left(\mathrm{CDCl}_{3}\right), 121.7,127.4,146.5,163.2,182.2,183.0$ Anal. Calcd for $\mathrm{C}_{18} \mathrm{H}_{28} \mathrm{O}_{3} \mathrm{~S}$ : C, 66.63; H, 8.70; S, 9.88. Found: C, 66.91; H, $8.65 ; \mathrm{S}, 9.81$.

2.5. 3-Dodecyloxy-2-formyl-5-methylhydroxyl Thiophene (5). A solution of ethyl alcohol $(60 \mathrm{~mL})$, 3-dodecyloxy-2,5diformyl thiophene $(3.69 \mathrm{~g}, 11.3 \mathrm{mmol})$, and sodium carbonate (4 drops) were allowed to stir at room temperature until all of the starting material dissolved. In a $50 \mathrm{~mL}$ Erlenmeyer flask, water $(4 \mathrm{~g})$ was added to potassium hydroxide flakes ( $3.22 \mathrm{~g}, 3 \mathrm{~mol}$ eq.) and the solid was first allowed to dissolve then placed in an ice bath to cool. Once the solution cooled, sodium borohydride $(0.2154 \mathrm{~g}, 0.367 \mathrm{~mol} \mathrm{eq}$.) was then added and stirred until it dissolved. After the sodium borohydride dissolved, that solution was added dropwise to the 3dodecyloxy-2,5-diformyl thiophene solution with vigorous stirring and allowed to react for five minutes. Next, in a warm water bath $\left(40^{\circ} \mathrm{C}\right)$ solid sodium bicarbonate $(5.82 \mathrm{~g}, 6.1 \mathrm{~mol}$ eq.) was added to the solution, and a light flow of air blew into the flask through a tube to slowly remove the ethanol. The solution was taken out of the warm bath after five minutes once the solution turned dark brown with a precipitate at the bottom of the flask. The product was extracted by first washing the solution with water $(7 \mathrm{~mL})$, and diethyl ether, and the aqueous layer was discarded. Then, water $(2 \mathrm{~mL})$ and sodium chloride (brine) were added to the organic layer and were discarded along with any inorganic salts. The organic layer was further washed with water $(2 \mathrm{~mL} \times 3)$ and aqueous layer with ether $(3 \mathrm{~mL} \times 4)$. The product was dried with $\mathrm{MgSO}_{4}$, and the solvent removed by rotary evaporator. The product was purified by column chromatography (1 EtAc:5 hexane used as eluent). The solid yellowish orange product had a $92.45 \%(3.43 \mathrm{~g})$ yield. ${ }^{1} \mathrm{H}$ NMR $\left(\mathrm{CDCl}_{3}\right): \delta 0.88(\mathrm{t}, 3 \mathrm{H})$, $1.26(\mathrm{~m}, 18 \mathrm{H}), 1.79(\mathrm{t}, 2 \mathrm{H}), 3.25(\mathrm{t}, 1 \mathrm{H}), 4.11(\mathrm{t}, 2 \mathrm{H}), 4.77(\mathrm{~d}$, $2 \mathrm{H}), 6.78(\mathrm{~s}, 1 \mathrm{H}), 9.89(\mathrm{~s}, 1 \mathrm{H}) .{ }^{13} \mathrm{C}$ NMR: $\delta$ 14.1, 22.6, 25.8, 29.6, 31.9, 60.7, 72.0, $76.6\left(\mathrm{CDCl}_{3}\right), 113.3,119.7,156.3,164.9$, 181.3 Anal. Calcd for $\mathrm{C}_{18} \mathrm{H}_{30} \mathrm{O}_{3} \mathrm{~S}: \mathrm{C}, 66.22 ; \mathrm{H}, 9.26 ; \mathrm{S}, 9.82$. Found: C, 66.10; H, 9.26; S, 9.66.

2.6. 5-Chloromethyl-3-dodecyloxy-2-formyl Thiophene (6). A solution of 3-dodecyloxy-2-formyl-5-methylhydroxyl thiophene $(1.515 \mathrm{~g}, 4.64 \mathrm{mmol})$, anhydrous DCM $(28 \mathrm{~mL})$, and pyridine $(0.734 \mathrm{~g}, 2 \mathrm{~mol}$ equ) were placed in a water bath with no ice $\left(22^{\circ} \mathrm{C}\right)$ until the starting material dissolved. Then, 1.2 molar equivalence of thionyl chloride $(0.406 \mathrm{~mL}, 0.662 \mathrm{~g})$ was diluted with anhydrous DCM in a syringe $(4 \mathrm{~mL})$ and added dropwise by syringe to the solution. Once the addition was completed, the solution was added to a $2: 1$ molar ratio of $2 \mathrm{~N}$ $\mathrm{HCl}(4.6 \mathrm{~mL})$ to pyridine and a few cubes of ice to quench the base. Extraction was done with ether and water $(2 \mathrm{~mL} \times 3)$. A small amount of sodium carbonate was added and monitored by litmus paper until reaction was neutral to slightly basic. The product was dried with $\mathrm{MgSO}_{4}$, and the solvent removed 


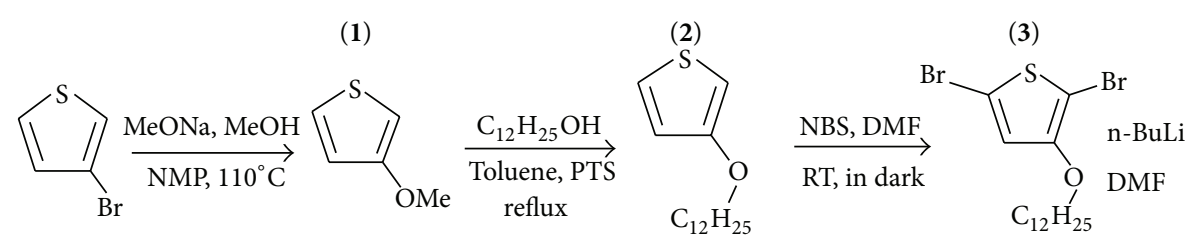

(4)

(5)

(6)

(7)

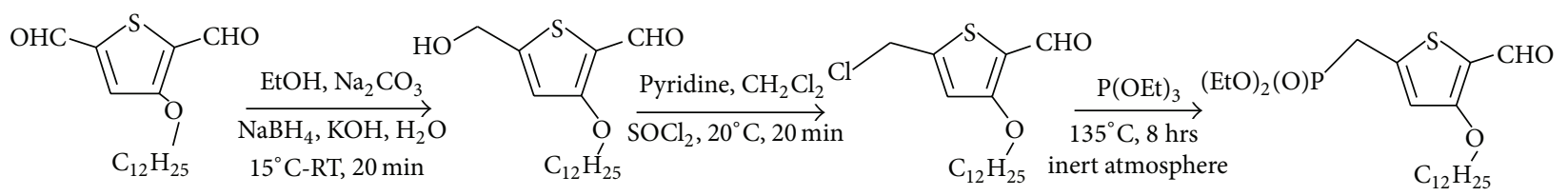

FIGURE 3: Synthetic scheme for asymmetric monomer 7 (3-dodecyloxy-2-formyl-thiophen-5-ylmethyl) phosphonic acid diethyl ester.

by rotary evaporator. No further purification was done on the sample, due to the possibility that it would decompose, so the yellowish orange solid product had a yield of $108 \%(1.714 \mathrm{~g})$. The sample contained a small amount of impurity. ${ }^{1} \mathrm{H}$ NMR $\left(\mathrm{CDCl}_{3}\right): \delta 0.87(\mathrm{t}, 3 \mathrm{H}), 1.26(\mathrm{~m}, 18 \mathrm{H}), 1.80(\mathrm{t}, 2 \mathrm{H}), 4.13(\mathrm{t}, 2 \mathrm{H})$, $4.66(\mathrm{~s}, 2 \mathrm{H}), 6.88(\mathrm{~s}, 2 \mathrm{H}), 9.96(\mathrm{~s}, 1 \mathrm{H}) .{ }^{13} \mathrm{C} \mathrm{NMR}: \delta 12.2,20.8$, 27.6, 30.0, 38.5, 70.2, $75.6\left(\mathrm{CDCl}_{3}\right), 114.6,119.6,147.4,161.8$, 179.1 .

2.7. (3-Dodecyloxy-2-formyl-thiophen-5-ylmethyl) Phosphonic Acid Diethyl Ester (7). A solution of 3-dodecyloxy-2-formyl5-methylhydroxyl thiophene (1.515 g, $4.64 \mathrm{mmol})$, anhydrous DCM $(28 \mathrm{~mL})$, and pyridine $(0.734 \mathrm{~g}, 2 \mathrm{~mol}$ eq. $)$ were placed in a water bath with no ice $\left(22^{\circ} \mathrm{C}\right)$ until the starting material dissolved. Then, 1.2 molar equivalence of thionyl chloride $(0.406 \mathrm{~mL}, 0.662 \mathrm{~g})$ was diluted with anhydrous DCM in a syringe $(4 \mathrm{~mL})$ and added dropwise by syringe to the solution. Once the addition was completed, the solution was added to a $2: 1$ molar ratio of $2 \mathrm{~N} \mathrm{HCl}(4.6 \mathrm{~mL})$ to pyridine and a few cubes of ice to quench the base. Extraction was done with ether and water $(2 \mathrm{~mL} \times 3)$. A small amount of sodium carbonate was added and monitored by litmus paper until reaction was neutral to slightly basic. The product was dried with $\mathrm{MgSO}_{4}$, and the solvent removed by rotary evaporator. No further purification was done on the sample, due to the possibility that it would decompose, so the yellowish orange solid product had a yield of $108 \%$ (1.714 g). The sample contained a small amount of impurity. ${ }^{1} \mathrm{H} \mathrm{NMR}\left(\mathrm{CDCl}_{3}\right): \delta$ $0.87(\mathrm{t}, 3 \mathrm{H}), 1.26(\mathrm{~m}, 18 \mathrm{H}), 1.80(\mathrm{t}, 2 \mathrm{H}), 4.13(\mathrm{t}, 2 \mathrm{H}), 4.66(\mathrm{~s}$, $2 \mathrm{H}), 6.88(\mathrm{~s}, 2 \mathrm{H}), 9.96(\mathrm{~s}, 1 \mathrm{H}) .{ }^{13} \mathrm{C} \mathrm{NMR}: \delta 12.2,20.8,27.6$, 30.0, 38.5, 70.2, $75.6\left(\mathrm{CDCl}_{3}\right), 114.6,119.6,147.4,161.8,179.1$.

2.8. Poly-(3-dodecyloxy-2,5-thienylene Vinylene) (8). Anhydrous THF $(2 \mathrm{~mL})$ and 1.2 molar equivalent of potassium t-butoxide $(0.0959 \mathrm{~g}, 0.854 \mathrm{mmol})$ were added to (3dodecyloxy-2-formyl-thiophen-5-ylmethyl) phosphonic acid diethyl ester $(0.318 \mathrm{~g}, .712 \mathrm{mmol})$, in a nitrogen atmosphere glove box. After 3.5 hours of reacting at $78^{\circ} \mathrm{C}$, the polymer was dissolved with THF and washed with methanol. The polymer was purified by filtration after washing with methanol. The bluish purple solid had a yield of $45.2 \%$ $(0.094 \mathrm{mg}) .{ }^{1} \mathrm{H} \mathrm{NMR}\left(\mathrm{CDCl}_{3}\right): \delta \quad 0.87\left(\mathrm{t},(3 \mathrm{H})_{n}\right), 1.25(\mathrm{~m}$,

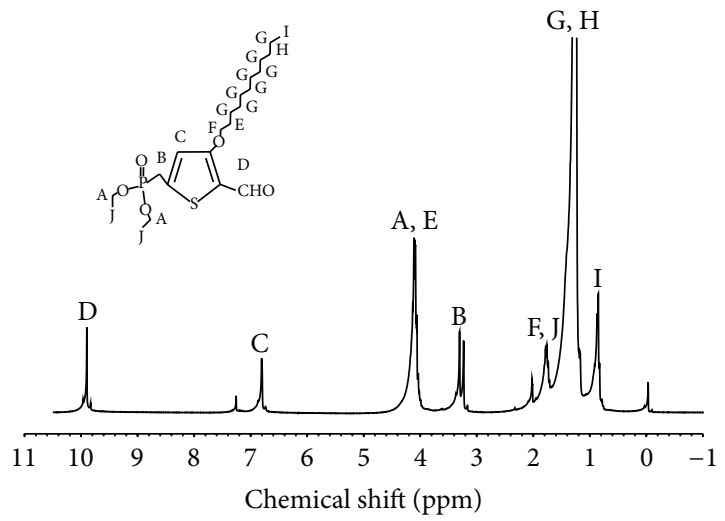

FIGURE 4: ${ }^{1}$ H NMR spectrum of (3-dodecyloxy-2-formyl-thiophen5 -ylmethyl) phosphonic acid diethyl ester.

$\left.(18 \mathrm{H})_{n}\right), 1.66\left(\mathrm{t},(2 \mathrm{H})_{n}\right), 4.05\left(\mathrm{t},(2 \mathrm{H})_{n}\right), 6.66,6.74,7.02,7.07$ ( $-\mathrm{C}=\mathrm{C}-$, aromatic3), 9.90, 10.0 (-CHO).

\section{Results and Discussion}

3.1. Synthesis. In order to promote $100 \%$ regioregularity in the polymer, a monomer was designed and synthesized to be monoaldehyde monophosphonate functionalized (asymmetric), as to eliminate any possibility of regiorandomness as seen in polymers of difunctionalized monomers [12, 14, 18]. The asymmetric PTV monomer, (3-dodecyloxy-2-formylthiophen-5-ylmethyl) phosphonic acid diethyl ester (7), was synthesized using a seven-step synthetic process (Figure 3). In order to form the asymmetric functional groups on the thiophene ring, the alkoxy thiophene underwent bromonation to form the dibromo groups (3), followed by formylation to form dialdehyde (4). Then, one of the dialdehydes was selectively reduced to a hydroxyl group (5), which was in the proceeding reaction chlorinated (6). The phosphonate functional group was formed successfully using MichaelisArbusov reaction (7). The ${ }^{1} \mathrm{H}$ NMR of the monomer (7) is shown in Figure 4.

The Horner-Emmons reactivity of the monomer 7 with potassium tert-butoxide (a nucleophile) is much lower than 


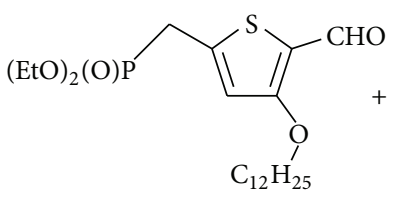

(7)

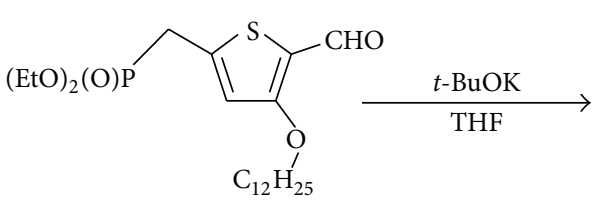

(8)

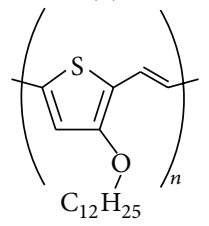

FIgURE 5: Polymerization of asymmetric monomer 7.

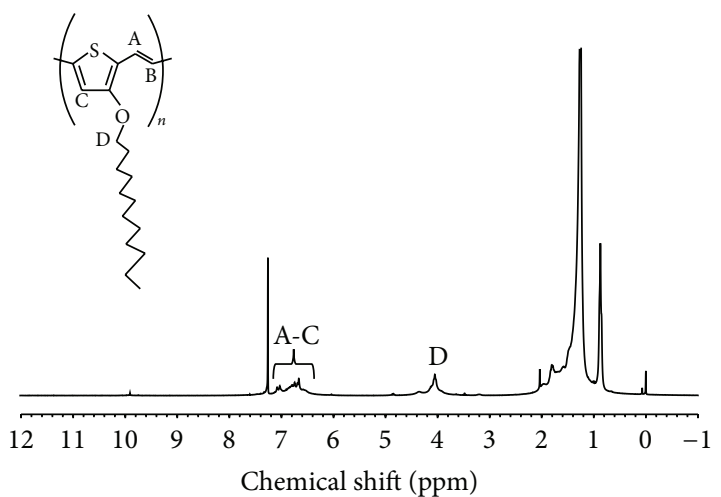

Figure 6: ${ }^{1}$ H NMR spectrum of poly (3-dodecyloxy-2,5-thienylene vinylene).

its alkyl version [1] possibly due to the lack of electron deficiency of the aldehyde group resulting in low reactivity. In the first trial and second trial, THF and t-BuOK were added to the monomer and allowed to react at room temperature for 10-20 minutes. In the first trial, the color of the reaction changed from reddish amber to green. However, the ${ }^{1}$ H NMR spectrum of the reaction mixture extract showed that there was only monomer in the solution; no polymer had formed. In the second trial the solution contained only $8 \%$ of the polymer. Since the first and second trials were not fully successful the solvent was changed from THF (a weakly polar aprotic solvent) to dimethylformamide (DMF) (stronger polar aprotic solvent) and allowed to react for $20 \mathrm{hrs}$. The change in solvent was to determine if the reaction environment to polymerize was polar enough. The ${ }^{1} \mathrm{H}$ NMR showed no reaction occurred, and only starting material remained. After it was concluded from the third trial that THF was a sufficient enough solvent for the reaction, the reaction conditions from the second trial were repeated with the exception of duration and temperature. The reaction was boiled for 10 minutes, and the ${ }^{1} \mathrm{H}$ NMR showed that only $15 \%$ of the monomer remained. Most of the polymer had formed. Once the reaction condition was determined, the remaining monomer reaction mixture was allowed to react for 3.5 hours at $78^{\circ} \mathrm{C}$ (Figure 5). The ${ }^{1} \mathrm{H}$ NMR shown in Figure 6 indicate the formation of polymer $(\mathbf{8})$ as evidenced from the loss of $-\mathrm{CH}_{2}$ doublet peak of $-\mathrm{CH}_{2} \mathrm{P}(\mathrm{O})\left(\mathrm{OCH}_{2} \mathrm{CH}_{3}\right)_{2}$ (position 5) and the - $\mathrm{CHO}$ peak (position 2) on the monomer (Figure 4). $-\mathrm{OCH}_{2}$ peaks from the dodecyloxy substituent on the monomer (position 3, D) appeared at $4.0 \mathrm{ppm}$ on the ${ }^{1}$ H NMR (Figure 6). Peaks from the phosphonate group also

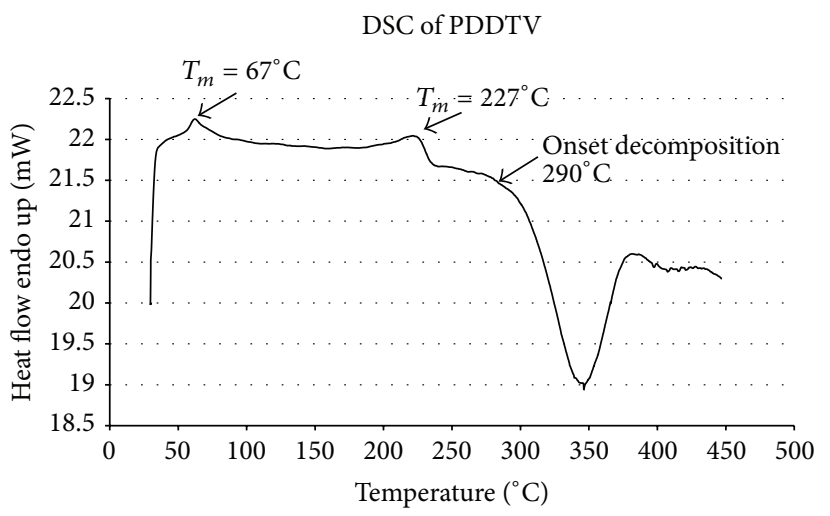

FIgURE 7: DSC plot of the PDDTV with a heating rate of $10^{\circ} \mathrm{C} / \mathrm{min}$ under nitrogen atmosphere.

disappeared. The broadening of the other peaks, especially those in the aromatic region $(\mathrm{A}-\mathrm{C})$, is another indication of the polymer formation.

3.2. Thermal Properties. Thermal properties of the PDDTV (polymer 8) were studied using TGA and DSC under Nitrogen atmosphere. The DSC thermogram (Figure 7) shows two endothermic peaks at $67^{\circ} \mathrm{C}$ and $227^{\circ} \mathrm{C}$. These data could indicate that this polymer exhibits polymorphic behavior similar to the reported comparable poly(3-alkyl thiophene)s $[19,20]$. The peak at $67^{\circ} \mathrm{C}$ could be attributed to the transition from crystalline state to liquid crystal (mesophase). The second peak at $227^{\circ} \mathrm{C}$ could be due to the transition from liquid crystal (mesophase) to an isotropic liquid $[19,20]$. The exothermic peak with an onset at $290^{\circ} \mathrm{C}$ is due to decomposition by reactions involving $\mathrm{C}=\mathrm{C}$ bonds. Figure 8 shows the TGA graph of the polymer. A weight loss of $5 \%$ starts at $\sim 330^{\circ} \mathrm{C}$.

3.3. Optoelectronic Properties. UV-vis absorption spectrum was used to determine the $\pi-\pi^{*}$ transition and the excitation energy gap of the polymer 8 backbone. The optical excitation energy gap was measured at $1.46 \mathrm{eV}$ from the onset of the UV-vis absorption peak in chloroform. A UV-vis spectrum of $\mathrm{P} 3 \mathrm{HT}$ in chloroform was also measured to compare the absorption shift of polymer (8) with that of P3HT. As shown in Figure 9, there is a red shift of polymer (8) absorption peak in comparison with P3HT, with a lambda max at $662 \mathrm{~nm}$ and a shoulder peak at $723 \mathrm{~nm}$ (P3HT has a lambda max absorption at $450 \mathrm{~nm}$ ). The shoulder at $723 \mathrm{~nm}$ could 


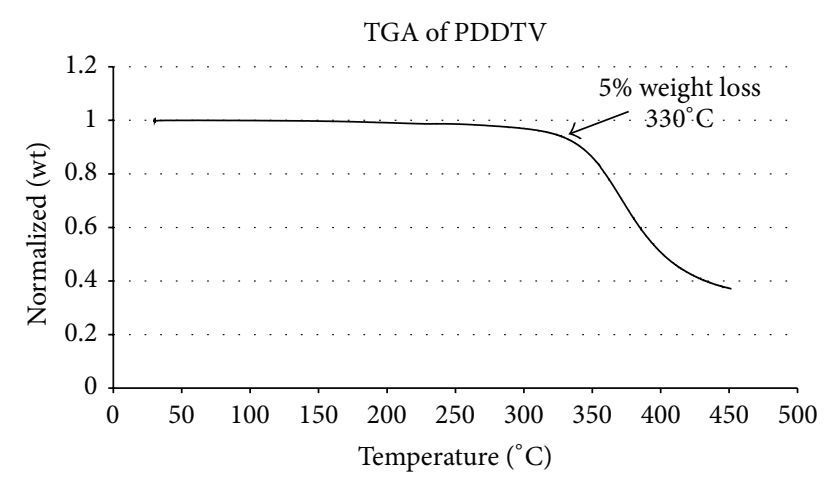

FIGURE 8: TGA plot of the PDDTV with a heating rate of $10^{\circ} \mathrm{C} / \mathrm{min}$ under nitrogen atmosphere.

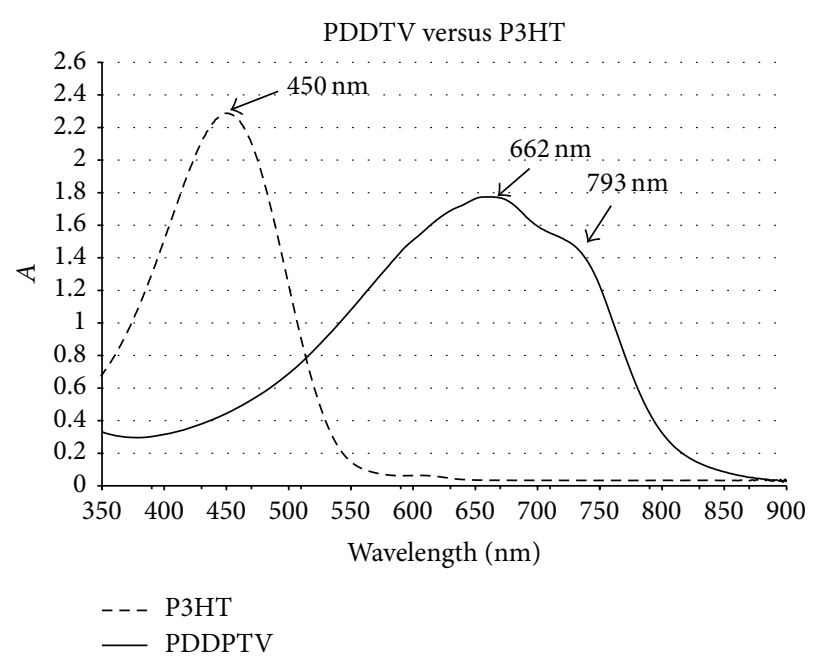

Figure 9: Absorption spectra of PDDTV versus P3HT.

be attributed to the vibronic fine structure seen in fully regioregular PTVs [19]. Photoluminescence measurements were conducted; however, there was no observable emission. This is in agreement with previous observations that PTVs have little or no luminescence due to the forbidden transition from the lowest energy excite state $\left(2 \mathrm{~A}_{\mathrm{g}}\right)$ to the ground state $\left(1 \mathrm{~A}_{\mathrm{g}}\right)[9]$.

3.4. Electrochemical Properties. The electrochemical properties of the polymer (8) were studied using cyclic voltammetry $(\mathrm{CV})$. The first onset of oxidation potential was used to determine the HOMO level. The LUMO level was calculated from the optical excitation energy gap combined with the measured HOMO $\left(\mathrm{E}_{\text {LUMO }}=\right.$ Optical Eg $\left.+\mathrm{E}_{\text {Hомо }}\right)$. The identification of the HOMO level position was based on the correlation between oxidation potentials and the HOMO orbitals were referenced to ferrocene. The $\mathrm{CV}$ graph of the polymer 8 is shown in Figure 10, and the results of the calculations are given in Table 1. The calculated HOMO level was $-4.79 \mathrm{eV}$ and the calculated LUMO using the above equation was $-3.33 \mathrm{eV}$. Since the oxidation is reversible, this polymer (8) is very stable for a variety of optoelectronic

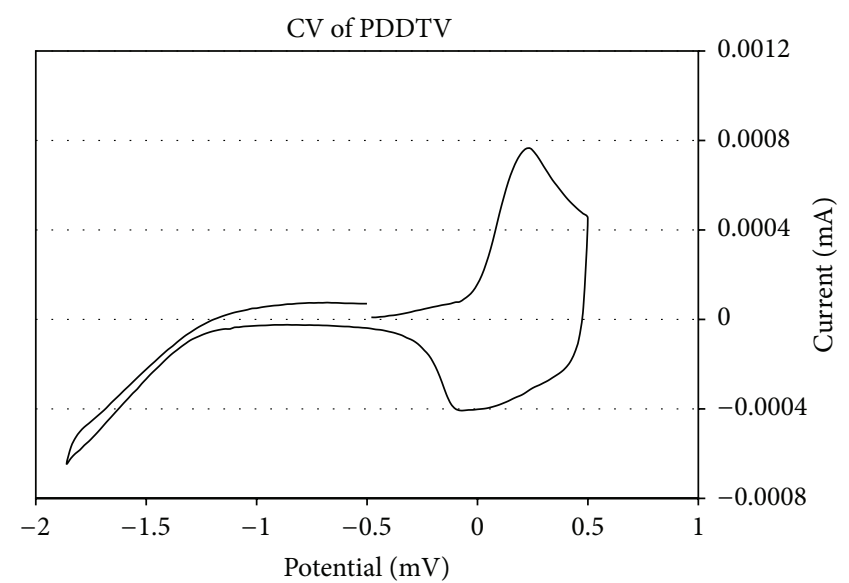

FIGURE 10: Cyclic voltamogram of the PDDTV dried on a platinum electrode immersed in a solution of $\mathrm{AgNO}_{3}$ and $\mathrm{Bu}_{4} \mathrm{NPF}_{6}$, in $\mathrm{CH}_{3} \mathrm{CN}$.

TABLE 1: Electrochemical onset potential and electronic energy levels of the polymer.

\begin{tabular}{lcc}
\hline$\varphi_{\text {ox }}(\mathrm{eV})$ & HOMO $(\mathrm{eV})$ & LUMO $(\mathrm{eV})$ \\
\hline 0.049 & -4.789 & -3.329 \\
\hline
\end{tabular}

applications as a donor or p-type material. The reduction is not reversible on the other hand, but that is not a major concern as this material will not be used as an N-type or acceptor material. For a donor material, a photovoltaic process is similar to an electrochemical redox process with the removal and recovery of electrons during the oxidation process.

\section{Conclusions}

Fully regioregular and terminally functionalized poly(3dodecyloxy-2,5-thienylene vinylene) or PDDTV has been successfully synthesized via Horner-Emmons reaction. Regioregularity coupling was ensured by the design and polymerization of an asymmetrically functionalized monomer (monoaldehyde monophosphonate). Monomer and polymer formation were confirmed by NMR. The synthetic method utilized in this research allows for an alternative approach for the synthesis of alkoxy-substituted PTV, while ensuring regioregularity. The method also provides facile approaches to synthesizing difunctionalized symmetric and asymmetric intermediate alkoxy-substituted thiophene compounds.

Optical characterization of the polymer showed a distinct red shift in the absorption spectra when compared to P3HT with a $\lambda_{\max }$ at $662 \mathrm{~nm}$ and a shoulder peak at $723 \mathrm{~nm}$. The measured optical energy gap is at $1.46 \mathrm{eV}$, which is an acceptable energy to capture photons in the highest irradiation range on the Earth's surface of 1 to $2 \mathrm{eV}$. This band gap is also as much as $\sim 0.3 \mathrm{eV}$ less than other reported PTVs [1-3, 7]. Electrochemical characterization of the polymer indicated 
that the electrooxidation process is reversible but the electroreduction process was nonreversible. The CV measured HOMO level is at $-4.79 \mathrm{eV}$. The polymer is partially soluble in common organic solvents such as tetrahydrofuran and chloroform, and solubility increases at elevated temperatures. The TGA and DSC showed that the polymer has good thermal stability with onsets of decomposition at $330^{\circ} \mathrm{C}$ and $290^{\circ} \mathrm{C}$, respectively.

This polymer shows great promise as a p-type material for photovoltaic application with its low optical energy gap and good thermal stability. Further optoelectronic studies including morphological studies and device fabrications will be studied and reported separately.

\section{Conflict of Interests}

The authors declare that there is no conflict of interests regarding the publication of this paper.

\section{Acknowledgments}

This material is based upon work supported, in part, from ARO award no. W911NF-11-1-0158, NSF award no. 1036494, and DOE award no. DE-EE-0004002. Lab assistance from Mrs. Rui Li and Mrs. Nicole Miller is greatly appreciated.

\section{References}

[1] C. Zhang, T. Matos, R. Li et al., "Poly(3-dodedyl-2,5thienylenevinylene)s from the Stille coupling and the Horner-Emmons reaction," Polymer Chemistry, vol. 1, no. 5, pp. 663-669, 2010.

[2] R. S. Loewe and R. D. McCullough, "Effects of structural regularity on the properties of poly(3-alkylthienylenevinylenes)," Chemistry of Materials, vol. 12, no. 10, pp. 3214-3221, 2000.

[3] C. Zhang, T. H. Nguyen, J. Sun et al., "Design, synthesis, characterization, and modeling of a series of $S, S$ dioxothienylenevinylene-based conjugated polymers with evolving frontier orbitals," Macromolecules, vol. 42, no. 3, pp. 663-670, 2009.

[4] R. Kroon, M. Lenes, J. C. Hummelen, P. W. M. Blom, and B. de Boer, "Small bandgap polymers for organic solar cells (polymer material development in the last 5 years)," Polymer Reviews, vol. 48, no. 3, pp. 531-582, 2008.

[5] M. L. Blohm, J. E. Pickett, and P. C. Van Dort, "Synthesis, characterization, and stability of poly(3,4-dibutoxythiophenevinylene) copolymers," Macromolecules, vol. 26, no. 11, pp. 2704-2710, 1993.

[6] C. Shi, Y. Yao, Y. Yang, and Q. Pei, "Regioregular copolymers of 3-alkoxythiophene and their photovoltaic application," Journal of the American Chemical Society, vol. 128, no. 27, pp. 89808986, 2006.

[7] E. E. Havinga, C. M. J. Mutsaers, and L. W. Jenneskens, "Absorption properties of alkoxy-substituted thienylenevinylene oligomers as a function of the doping level," Chemistry of Materials, vol. 8, no. 3, pp. 769-776, 1996.

[8] A. Iraqi, G. W. Barker, and D. F. Pickup, "Synthesis and characterisation of functionalised thiophene copolymers with electron donor and acceptor substituents," Reactive and Functional Polymers, vol. 66, no. 1, pp. 195-200, 2006.
[9] J. Hou, Z. Tan, Y. He, C. Yang, and Y. Li, "Branched poly(thienylene vinylene)s with absorption spectra covering the whole visible region," Macromolecules, vol. 39, no. 14, pp. 46574662, 2006.

[10] K. van de Wetering, C. Brochon, C. Ngov, and G. Hadziioannou, "Design and synthesis of a low band gap conjugated macroinitiator: toward rod-coil donor-acceptor block copolymers," Macromolecules, vol. 39, no. 13, pp. 4289-4297, 2006.

[11] J. C. Speros, B. D. Paulsen, S. P. White et al., "An ADMET route to low-band-gap poly(3-hexadecylthienylene vinylene): a systematic study of molecular weight on photovoltaic performance," Macromolecules, vol. 45, no. 5, pp. 2190-2199, 2012.

[12] H. Diliën, A. Palmaerts, M. Lenes et al., "A deeper insight into the dithiocarbamate precursor route: synthesis of soluble poly(thienylene vinylene) derivatives for photovoltaic applications," Macromolecules, vol. 43, no. 24, pp. 10231-10240, 2010.

[13] F. Banishoeib, P. Adriaensens, S. Berson et al., “The synthesis of regio-regular poly(3-alkyl-2,5-thienylene vinylene) derivatives using lithium bis(trimethylsilyl)amide (LHMDS) in the dithiocarbamate precursor route," Solar Energy Materials and Solar Cells, vol. 91, no. 11, pp. 1026-1034, 2007.

[14] S. Gillissen, A. Henckens, L. Lutsen, D. Vanderzande, and J. Gelan, "Synthesis of a processible high molecular weight poly(thienylene vinylene). polymerisation and thin-film transistor properties," Synthetic Metals, vol. 135-136, pp. 255-256, 2003.

[15] M. A. Keegstra, T. H. A. Peters, and L. Brandsma, "Efficient procedures for the $\mathrm{Cu}(\mathrm{I})$-catalyzed methoxylation of 2-and 3bromothiophene," Synthetic Communications, vol. 20, pp. 213216, 1990.

[16] K. Faïd, R. Cloutier, and M. Leclerc, "Design of novel electroactive polybithiophene derivatives," Macromolecules, vol. 26, no. 10, pp. 2501-2507, 1993.

[17] N. Agarwal, S. P. Mishra, A. Kumar, C.-H. Hung, and M. Ravikanth, "Synthesis and crystal structure of 2,3,12,13tetraalkoxy-21, 23-dithiaporphyrins," Chemical Communications, no. 22, pp. 2642-2643, 2002.

[18] C. Girotto, D. Cheyns, T. Aernouts et al., "Bulk heterojunction organic solar cells based on soluble poly(thienylene vinylene) derivatives," Organic Electronics: Physics, Materials, Applications, vol. 9, no. 5, pp. 740-746, 2008.

[19] C. Zhang, J. Sun, R. Li, S.-S. Sun, E. Lafalce, and X. Jiang, "Poly(3-dodecylthienylenevinylene)s: regioregularity and crystallinity," Macromolecules, vol. 44, no. 16, pp. 6389-6396, 2011.

[20] V. Causin, C. Marega, A. Marigo, L. Valentini, and J. M. Kenny, "Crystallization and melting behavior of poly(3-butylthiophene), poly(3-octylthiophene), and poly(3-dodecylthiophene)," Macromolecules, vol. 38, no. 2, pp. 409-415, 2005. 

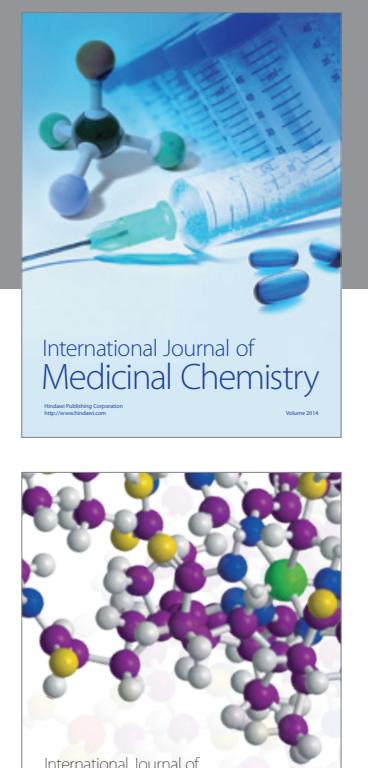

\section{Carbohydrate} Chemistry

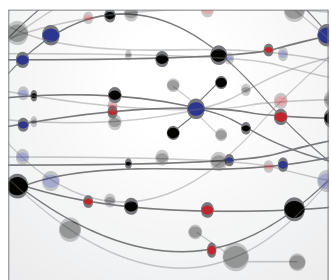

The Scientific World Journal
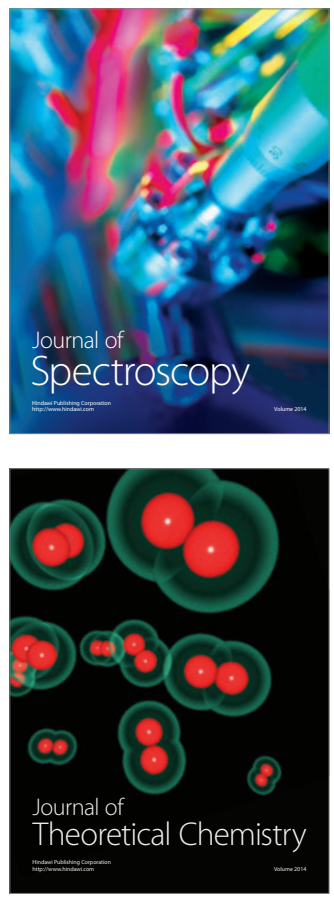
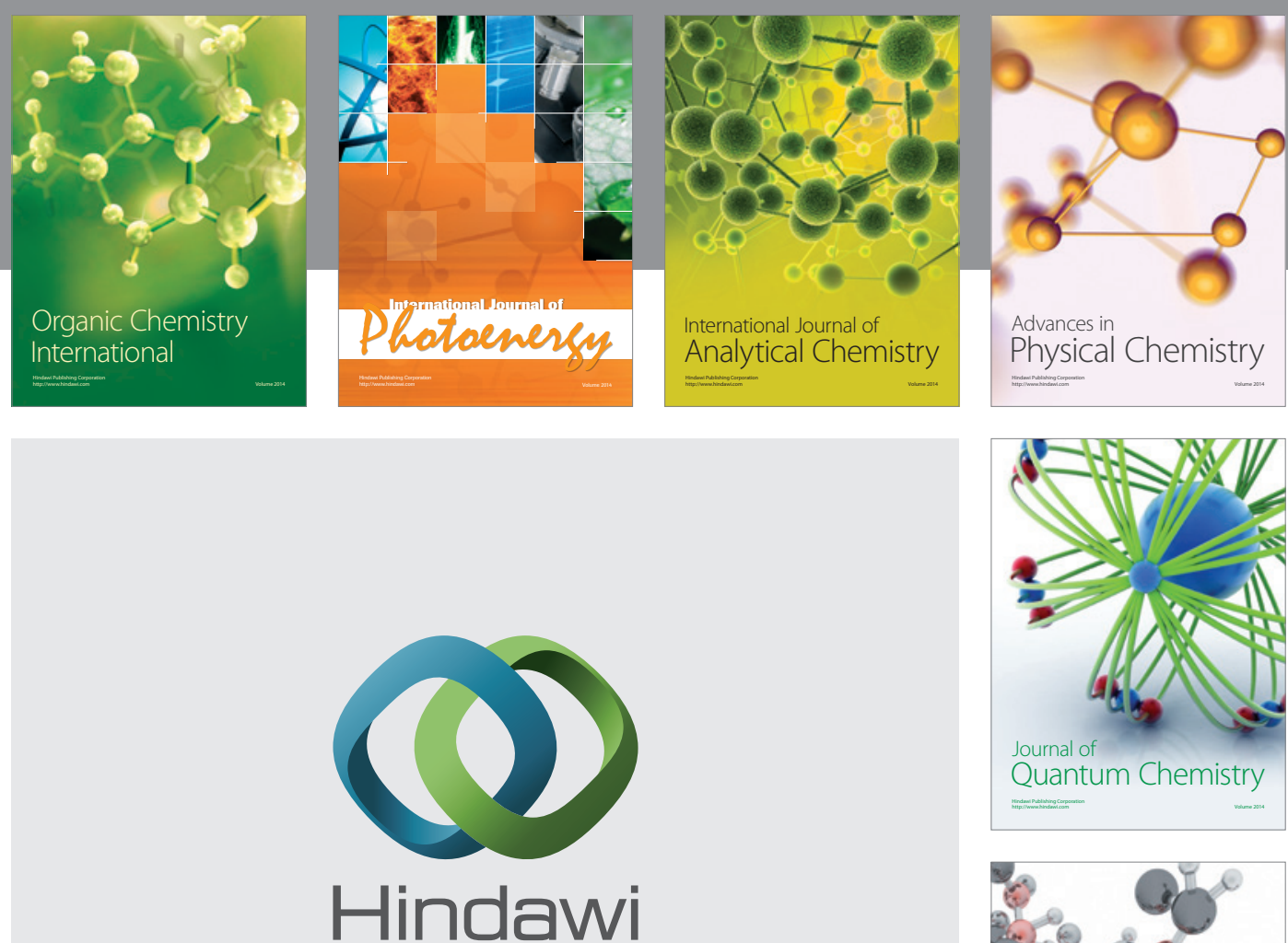

Submit your manuscripts at

http://www.hindawi.com

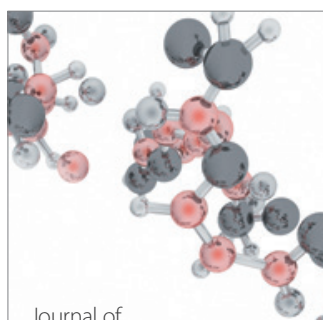

Analytical Methods

in Chemistry

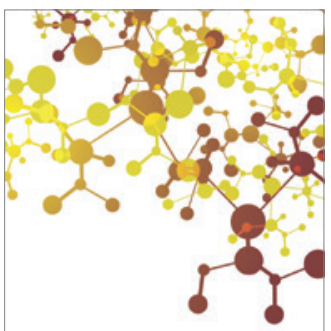

Journal of

Applied Chemistry

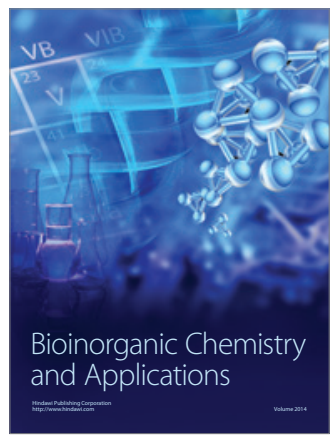

Inorganic Chemistry
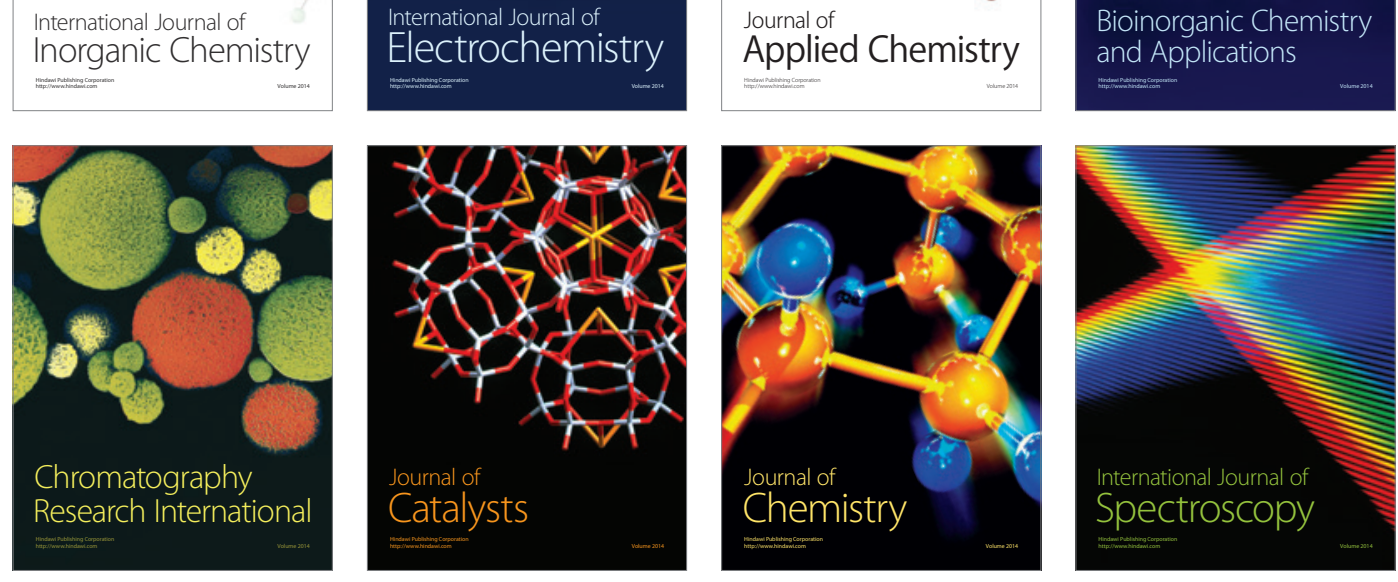